\title{
НОВЫЕ АСПЕКТЫ СТРУКТУРНОГО ДИЗАЙНА НА ОСНОВЕ КОМПЛЕКСОВ РТ(II) - АНАЛОГОВ ЦИСПЛАТИНА И КАРБОПЛАТИНА
}

\section{Т.А. Подругина' ${ }^{1}$ А.А. Логвинов ${ }^{1}$, А.А. Назаров', Е.Д. Никольская ${ }^{2}$, М.В. Фомичева², Н.Г. Яббаров²}

${ }^{1}$ Химический факультет, Московский государственный университет им. М.В. Ломоносова, 119991, Российская Федерация, Москва, ГСП-1, Ленинские горы, д. 1, стр. 3.

2Институт биохимической физики им. Н. М. Эмануэля РАН, 119334, Российская Федерация, Москва, ул. Косыгина, 4.

DOI: 10.19163/MedChemRussia2021-2021-51

E-mail: podrugina@mail.ru

Популярным направлением модификации комплексов Pt(II) является варьирование структурных фрагментов в базовом соединении, обладающим известной противоопухолевой активностью, что позволяет преодолевать фенотип множественной лекарственной устойчивости (МЛУ) и снижать системную токсичность $[1,2]$. Такая стратегия имеет два вектора развития - варьирование уходящих групп и замена лиганда-носителя. Настоящее исследование включает в себя разработку подходов к новым аналогам цисплатина и карбоплатина. Было установлено, что сочетание 1 -алкил- 1 -пиразолов в качестве лигандов-носителей и иодид-ионов в качестве уходящих групп в комплексах платины (II) многократно увеличивает цитотоксичность по сравнению с цисплатином. Был проведен синтез новых структурных аналогов на основе 3-гидроксикарбоплатина и исследована зависимость активности комплексов от структуры лигандов в эксперименте по определению цитотоксической активности в отношении опухолевых клеток и показано, что это направление модификации карбоплатина имеет структурные предпосылки для создания тераностического препарата белково-векторной доставки на основе производного платины и сополимера молочной и гликолевой кислот (PLGA).

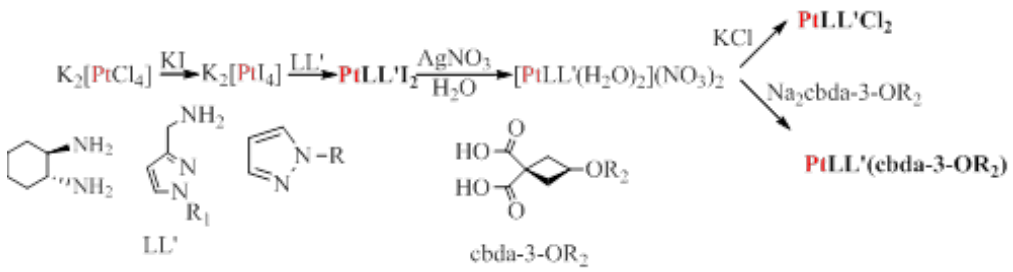

Работа проведена при финансовой поддержке гранта РФФИ (проект № 19-53-26002).

\section{Литература}

[1] L. Bai, C. Gao, Q. Liu, C. Yu, Z. Zhang, L. Cai, B. Yang, Y. Qian, J. Yang, X. Liao, Eur. J. Med. Chem., 2017, 140, 349-382.

[2] K.M. Deo, D.L. Ang, B. McGhie, A. Rajamanickam, A. Dhiman, A. Khoury, J. Holland, A. Bjelosevic, B. Pages, C. Gordon, J. R. Aldrich-Wright, Coord. Chem. Rev., 2018, 375, 148-163. 